\title{
Teknologi pengolahan air gambut menjadi air bersih dengan sistem koagulan dan filtrasi di Desa Buluh Cina, Kecamatan Siak Hulu, Kampar
}

\author{
Juandi M*, Usman Malik, Salomo, dan Antonius Surbakti \\ Universitas Riau \\ *juandi@lecturer.unri.ac.id
}

\begin{abstract}
Abstrak. Air gambut gambut yang melimpah di Desa Buluh Cina, Kecamatan Siak Hulu, Kampar merupakan potensi alam yang dapat digunakan untuk keperluan memasak dan mandi dengan cara mengolah air gambut menjadi air bersih yang layak di konsumsi. Tujuan dari kegiatan pengabdian ini adalah untuk pengolahan air gambut menjadi air bersih. Metode yang digunakan dalam kegiatan pengabdian ini adalah dengan menggunakan teknologi koagulan dan filtrasi. Media filtrasi dan koagulan yang optimal ini digunakan untuk pengolahan air gambut terdiri dari biosand filter dengan dua media yaitu batu apung (pumice) dan pasir kuarsa. Hasil pengabdian menurunkan kadar kekeruhan dan warna air gambut serta menurunkan kadar organik, sehingga air gambut yang diolah menjadi air bersih yang layak minum. Nilai $\mathrm{pH}$ terendah sebelum filterisasi yaitu sebesar 5,93 dan $\mathrm{pH}$ tertinggi terdapat pada sebelum filterisasi yaitu 6,23. Artinya sebelum difilter air gambut bersifat asam lemah. Hasil sampel terendah setelah filterisasi dengan saringan pasir lambat yaitu sebesar 6,42 dan $\mathrm{pH}$ tertinggi setelah filterisasi sebesar 7,5 yang artinya air bersifat basa lemah. Batas $\mathrm{pH}$ air yang baik adalah 6,5 sampai dengan 8,5 sehingga pengabdian ini membuktikan saringan pasir lambat dinilai cukup efektif untuk mengoptimalkan $\mathrm{pH}$ air. Total dissolved solid (TDS) merupakan salah satu parameter untuk menentukan suatu kualitas air, TDS menunjukkan jumlah padatan zat terlarut pada air. Hasil tentang TDS air gambut bahwa nilai TDS terendah sebelum filterisasi yaitu sebesar $46 \mathrm{mg} / \mathrm{L}$ dan TDS tertinggi terdapat pada sebelum filterisasi yaitu sebesar 49 $\mathrm{mg} / \mathrm{L}$. Hasil sampel terendah setelah filterisasi dengan saringan pasir lambat yaitu $49 \mathrm{mg} / \mathrm{L}$ dan TDS tertinggi setelah filterisasi sebesar $83 \mathrm{mg} / \mathrm{L}$.
\end{abstract}

Kata kunci: air; filterisasi; gambut; koagulan; teknologi

\begin{abstract}
The abundant peat water in Buluh Cina Village, Siak Hulu Subdistrict, Kampar is a natural potential that can be used for cooking and bathing purposes by processing peat water into clean water that is suitable for consumption. The purpose of this service activity is to treat peat water into clean water. The method used in this service activity is using coagulant and filtration technology. The optimal filtration and coagulant media used for peat water treatment consists of biosand filters with two media namely pumice and quartz sand. The dedication results reduce turbidity and color of peat water and reduce organic content, so that peat water is processed into clean drinking water. The lowest $\mathrm{pH}$ value before filtering is equal to 5.93 and the highest $\mathrm{pH}$ is found before filtering which is 6.23 . This means that before filtering peat water is weak acidic. The lowest sample results after filtration with a slow sand filter that is equal to 6.42 and the highest $\mathrm{pH}$ after filtration of 7.5, which means that water is weakly basic. A good pH limit for water is 6.5 to 8.5 so this service proves that slow sand filters are considered effective enough to optimize water $\mathrm{pH}$. Total dissolved solid (TDS) is one of the parameters for determining a water quality, TDS shows the amount of solute solids in water. The result of peat water TDS is that the lowest TDS value before filtration is $46 \mathrm{mg} / \mathrm{L}$ and the highest TDS is found before filtering which is $49 \mathrm{mg} / \mathrm{L}$. The lowest sample results after filtration with slow sand filter is $49 \mathrm{mg} / \mathrm{L}$ and the highest TDS after filtering is $83 \mathrm{mg} / \mathrm{L}$.
\end{abstract}

Keywords: water; filtration; peat; coagulant; technology

To cite this article: Juandi M, U. Malik, Salomo, \& A. Surbakti. 2019. Teknologi pengolahan air gambut menjadi air bersih dengan sistem koagulan dan filtrasi di Desa Buluh Cina, Kecamatan Siak Hulu, Kampar. Unri Conference Series: Community Engagement 1: 325-332 https://doi.org/10.31258/unricsce.1.325-332

(C) 2019 Authors

Peer-review under responsibility of the organizing committee of Seminar Nasional Pemberdayaan Masyarakat 2019 


\section{PENDAHULUAN}

Air merupakan komponen penting bagi kehidupan makhluk hidup di bumi. Semakin meningkatnya jumlah makhluk hidup maka semakin meningkat kebutuhan air yang diperlukan sehingga air bersih perlu dijaga agar tidak tercemar. Sumur cincin merupakan salah satu sumber yang dapat digunakan untuk mendapatkan air. Sumur cincin banyak digunakan oleh masyarakat karena pembuatannya relatif mudah karena menggunakan peralatan yang sangat sederhana dan harga yang murah. Air minum di Indonesia terdiri dari beberapa sumber, yaitu sumur cincin $(22,5 \%)$, air sumur bor $(12,8 \%)$ serta air isi ulang (21\%) (Kemenkes, 2014). Tingkat pemakain air sumur cincin yang tergolong banyak dimasyarakat harus lebih diperhatikan, karena sumur cincin sangat mudah terkontaminasi melalui rembesan yang berada disekitar sumur seperti kotoran manusia, pembuangan kotoran hewan dan limbah sumur itu sendiri.

Desa Buluh Cina Kecamatan Siak Hulu dalam Kabupaten Kampar merupakan salah satu daerah yang masyarakatnya masih banyak menggunakan sumur cincin. Sumur cincin yang berada pada daerah ini memiliki air yang tidak layak dikonsumsi karena airnya memiliki warna yang tidak jernih atau kemerahan/coklat .

Metode yang dapat dilakukan untuk memperbaiki kualitas air diantaranya adalah metode saringan kain katun, metode saringan pasir cepat dan metode saringan pasir lambat. Penjernihan air menggunakan kain katun merupakan teknik yang sangat sederhana. Metode ini memiliki kelemahan, yaitu tidak dapat menyaring bakteri, bau serta parameter lainnya secara efektif. Dua metode lainnya yaitu saringan pasir cepat dan saringan pasir lambat merupakan metode yang menggunakan pasir dan kerikil sebagai media penyaringannya. Metode saringan pasir cepat dikenal dengan proses penyaringan yang cepat namun metode ini kurang efektif dalam mengatasi masalah bau dan rasa, serta debit air yang besar membuat bakteri tidak tersaring secara efektif.

Metode saringan pasir lambat mempunyai kandungan kuarsa yang tinggi dan ukuran butiran sangat kecil (Taweel dan Ali, 2000). Proses filterisasi pada saringan pasir lambat adalah dengan cara memisahkan air dari kandungan kontaminan seperti partikel tersuspensi dan koloid, serta bakteri, dengan melewatkan air pada suatu media berpori. Media berpori yang paling sering digunakan adalah pasir, karena pasir mudah didapatkan, biaya yang murah dan hasil pengolahan yang diberikan juga sangat baik (Longsdon et al., 2002).

Derajat keasaman $(\mathrm{pH})$ merupakan suatu parameter fisis yang digunakan untuk menyatakan intensitas keadaan asam atau basa suatu larutan. Parameter $\mathrm{pH}$ harus dipertimbangkan karena derajat keasaman air mempengaruhi aktivitas pengolahan yang akan dilakukan misalnya disinfeksi, koagulasi kimiawi, perlunakan air dan dalam pencegahan korosi (Sutrisno, 1987).Air bersifat asam apabila $\mathrm{pH}<7$, air dengan nilai $\mathrm{pH}=7$ adalah netral, sedangkan $\mathrm{pH}>7$ dikatakan kondisi air bersifat basa (Effendi, 2003). Tinggi atau rendahnya $\mathrm{pH}$ pada air tidak berpengaruh pada kesehatan, akan tetapi apabila air dengan $\mathrm{pH}<6,5$ akan menyebabkan korosi pada metal yang melarutkan unsur-unsur timbal, tembaga, kadnium yang bersifat beracun. Demikian pula jika $\mathrm{pH}>8,5$ yang bersifat basa dapat membentuk endapan (kerak) pada pipa air yang terbuat dari metal (Sudadi, 2003).

\section{MASALAH}

Berdasarkan identifikasi diatas maka permasalahan yang ada di Desa Buluh Cina Kecamatan Siak Hulu Kabupaten Kampar, yaitu:

1. Adanya kondisi air gambut sebagai potensi yang belum dikelola.

2. Adanya keluhan masyarakat tentang kondisi lingkungan atau air berwarna coklat/merah.

3. Masyarakat belum mengenal Teknologi pengolahan air gambut menjadi air bersih.

\section{METODE}

Teknik Filterisasi dibuat menggunakan drum plastik yang diisi dengan beberapa bahan seperti yang ditunjukkan pada Gambar 1.

Metode filterisasi yang digunakan adalah metode filterisasi saringan pasir lambat. Metode filterisasi saringan pasir lambat merupakan, teknologi pengolahan air yang sangat sederhana dengan hasil air bersih dengan kualitas yang baik. Sistem saringan pasir lambat ini mempunyai keunggulan antara lain tidak memerlukan bahan kimia (koagulan) yang mana bahan kimia ini merupakan kendala sering dialami pada proses pengolahan air di daerah pedesaan. 


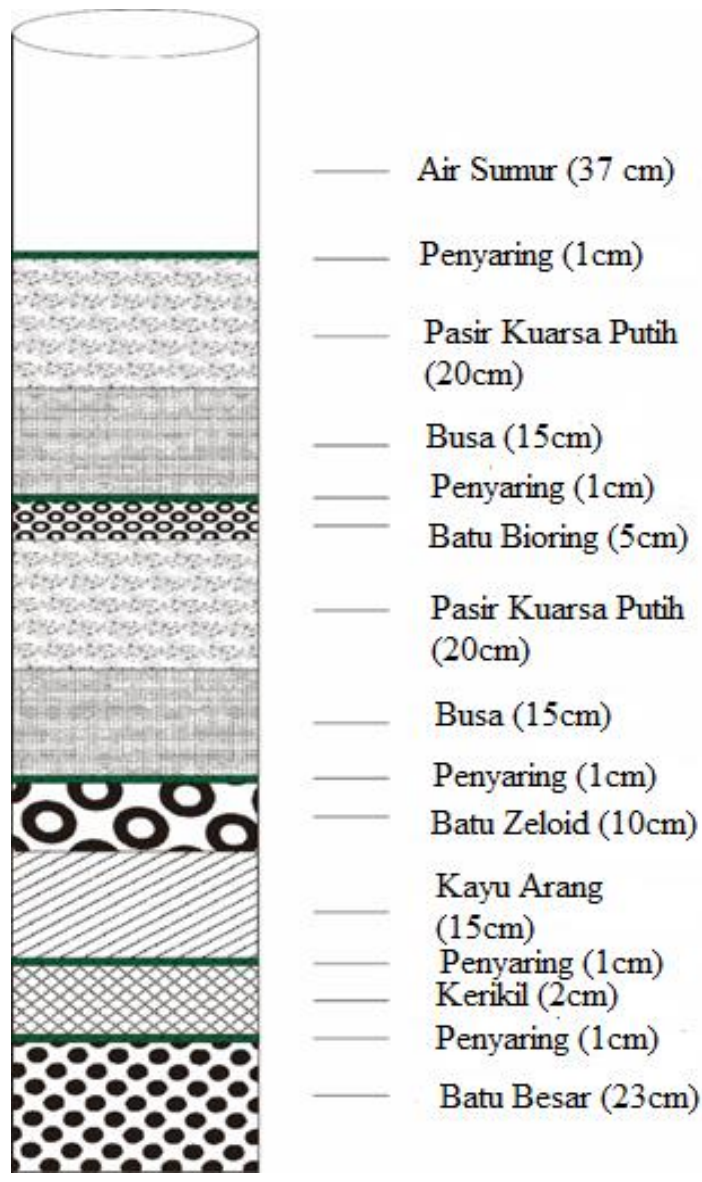

Gambar 1. Bahan Saringan Filterisasi

Bahan-bahan filterisasi saringan pasir lambat sebagai berikut:

1. Air Gambut

Bahan utama yang di teliti adalah air gambut di Sekitar Kampus UIN Suska Riau Kota Pekanbaru, Air gambut diambil sebanyak 8 liter per sampel

2. Pasir Kursa Putih

Pasir kuarsa putih merupakan salah satu jenis pasir yang paling umum kita temui. Pasir kuarsa putih sendiri pada dasarnya berasal dari erosi alias pengikisan dari batu-batuan dan juga berbagai benda alam yang mengalami pengikisan, baik karena air maupun udara. Pasir kuarsa putih, memiliki bentuk kristal kuarsa, atau yang dalam bahasa inggris seringkali dikenal dengan istilah quartz.

3. Kayu Arang

Kayu Arang adalah arang yang terbuat dari bahan dasar kayu. Arang kayu paling banyak digunakan untuk keperluan memasak seperti yang dijelaskan sebelumnya. Sedangkan penggunaan arang kayu yang lainnya adalah sebagai penjernih air, penggunaan dalam bidang kesehatan, dan masih banyak lagi. Bahan kayu yang digunakan untuk dibuat arang kayu adalah kayu yang masih sehat, dalam hal ini kayu belum membusuk.

4. Kerikil

Batu Kerikil (Pebbles) sebenarnya menunjukkan besaran butir pasir, dapat dikategorikan sebagai Batu Pasir yang banyak mengandung silika. Umumnya bertekstur halus atau sering juga disebut kerikil jagung dan berbentuk bulat terbentuk akibat dari pecahan batu gunung yang kemudian terseret air hingga ke laut dan selama ribuan tahun saling beradu sesamanya dan terkikis air, karena itu diperoleh di daerah pesisir pantai. Ukuran kerikil yang selalu digunakan ialah antara $2 \mathrm{~mm}-75 \mathrm{~mm}$ dan bentuk kerikil tidak homogen.

5. Batu Zeolit 
Batu Zeolit banyak digunakan sebagai media pertukaran ion dalam proses pemurnian air, baik untuk kebutuhan rumah tangga, komersial, maupun industri. Batu zeolit memiliki potensi memberi pemisahan yang tepat dan spesifik dari gas termasuk penghilang $\mathrm{H}_{2} \mathrm{O}, c_{o} 2$, dan $\mathrm{SO}_{2}$.

6. Batu Besar

Batu besar merupakan salah satu bahan filterisasi yang digunakan. Batu besar ini berfungsi untuk menyerap air yang telah terkontaminan.

7. Batu Bioring

Memiliki fungsi yang mirip dengan batu Zeloit yaitu untuk menyerap bakteri.

Keunggulan saringan pasir lambat:

1. Tidak memerlukan bahan kimia, sehingga operasinya sangat murah.

2. Dapat menghilangkan zat besi, mangan dan warna serta kekeruhan.

3. Dapat menghilangkan ammonia dan polutan organik, karena proses penyaringan berjalan secara fisika dan biokimia

4. Sangat cocok untuk daerah pedesaan dan proses pengolahan sangat sederhana

5. Perawatan mudah karena pencucian media penyaring (pasir) dilakukan dengan cara membuka kran penguras, sehingga air hasil saringan yang berada diatas lapisan pasir berfungsi sebagai air pencuci. Dengan demikian pencucian pasir dapat dilakukan tanpa pengerukan media pasirnya.

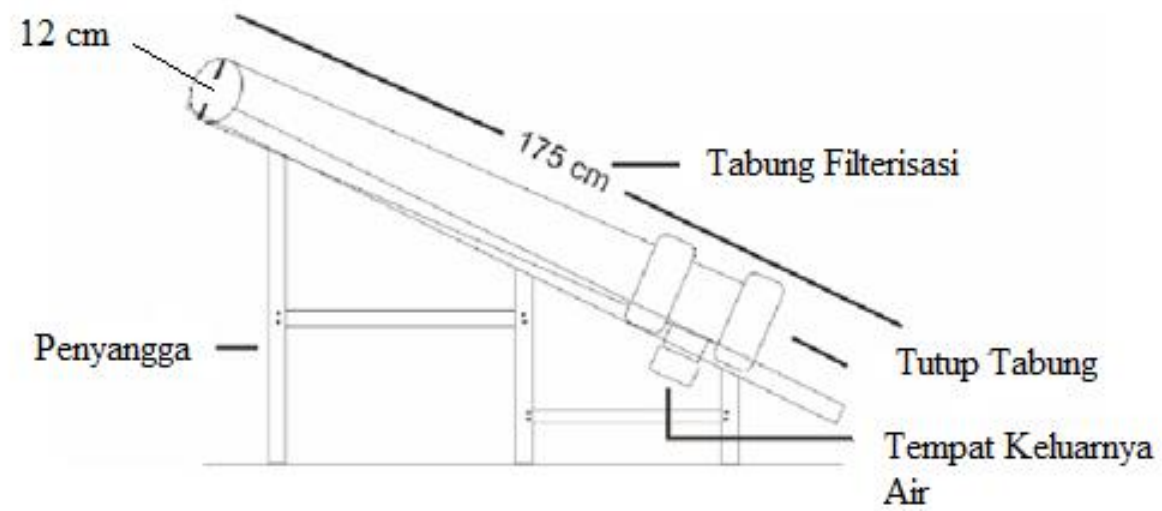

Gambar 2. Tabung Saringan Pasir Lambat

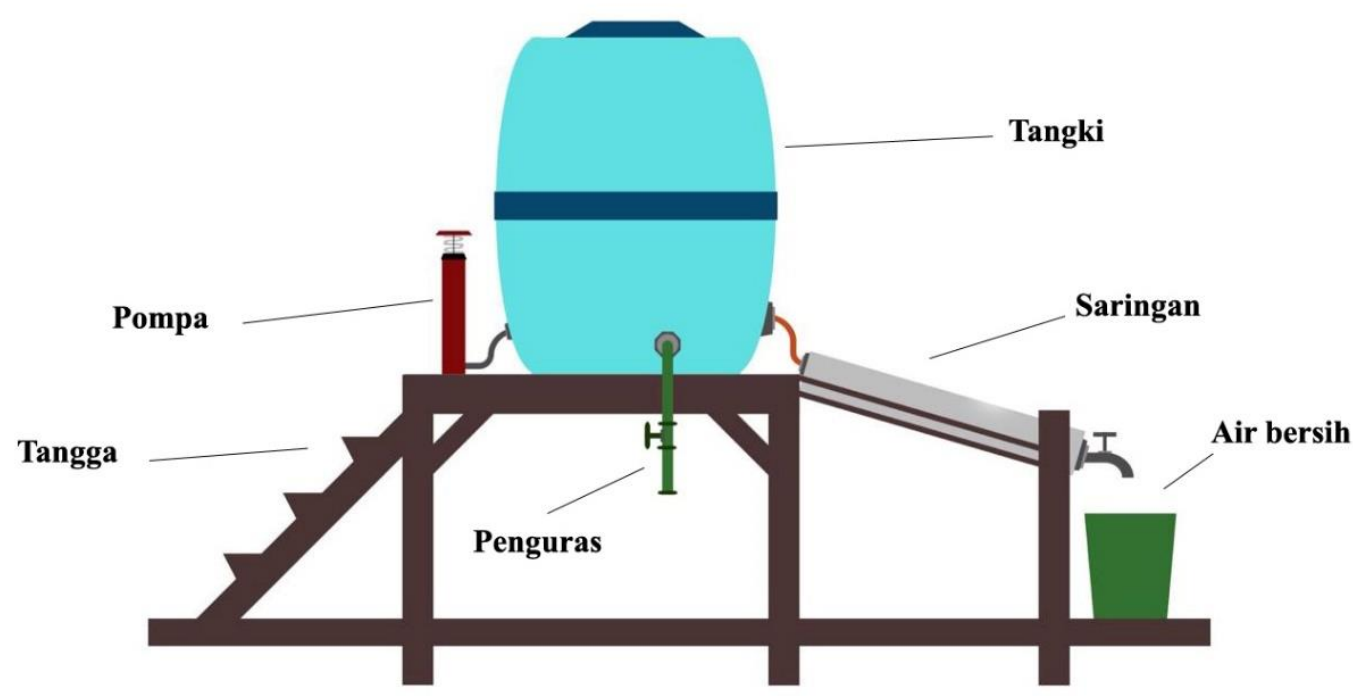

Gambar 3. Alat Filterisasi 
Cara kerja alat Filterisasi Saringan Pasir Lambat:

Filterisasi air gambut dengan menggunakan metode saringan pasir lambat langkah pertama adalah memasukkan sampel air gambut ke dalam tangki air sebanyak 8 liter. Kemudian, tambahkan tawas sebanyak 3 gram atau setengah sendok makan dan diaduk selama 2 sampai 3 menit hingga tawas larut dengan air. Tawas yang berfungsi sebagai penangkap partikel halus dalam air dan mengubahnya menjadi endapan membantu dalam proses filterisasi air gambut. Setelah itu dengan memasukkan oksigen kedalam tangki air dengan menggunakan pompa selama 2 menit. Fungsi pompa pada alat filterisasi saringan pasir lambat ini adalah untuk memberikan tekanan pada permukaan air, karena diperlukan tekanan tinggi untuk membuat gas larut ke dalam air. Air yang banyak mengandung oksigen tentunya bagus untuk dikonsumsi. Diamkan air selama 2 jam hingga terlihat endapan pada bagian bawah tangki air. Kemudian, buka kran dan biarkan air mengalir kedalam pipa PVC yang telah diisi bahan-bahan filter. Air yang telah difilter lalu ditampung kedalam sebuah ember atau botol yang telah dibersihkan.

Fungsi masing-masing Instrument pada alat filterisasi saringan pasir lambat:

1. Tangki

Fungsi Tangki Air adalah untuk menampung air baku maupun air product hasil olahan. Pada penelitian ini tangki dapat menampung air gambut lebih dari 20 liter.

2. Pompa

Fungsi pompa adalah untuk mensuplay oksigen pada sampel air gambut. Untuk memberikan tekanan pada permukaan air, karena diperlukan tekanan tinggi untuk membuat gas larut ke dalam air. Air yang banyak mengandung oksigen tentunya bagus untuk dikonsumsi.

3. Penguras

Penguras berfungsi sebagai tempat pembuangan endapan-endapan air gambut. Pada saat pemberian tawas pada sampel, tawas yang berfungsi sebagai penangkap partikel halus pada air gambut akan mengubahnya menjadi endapan-endapan.

4. Saringan

Saringan berfungsi sebagai tempat dari bahan-bahan filterisasi saringan pasir lambat dan dapat mengolahan air yang tercemar atau yang tidak dapat di konsumsi menjadi dapat dikonsumsi.

\section{HASIL DAN KETERCAPAIAN}

\section{Pelaksanaan Pengabdian}

Pelaksanaan pengabdian ini di bagi atas dua tahapan yaitu: (a) Tahapan di Kelas, tahapan ini terdiri dari penyampaian materi di ruangan/aula Desa Buluh Cina Kecamatan Siak Hulu Kabupaten Kampar Provinsi Riau. (b) Tahapan di Lapangan, tahapan ini untuk praktek langsung pengolahan air gambut menjadi air bersih yang ada di Desa Buluh Cina Kecamatan Siak Hulu Kabupaten Kampar Provinsi Riau.

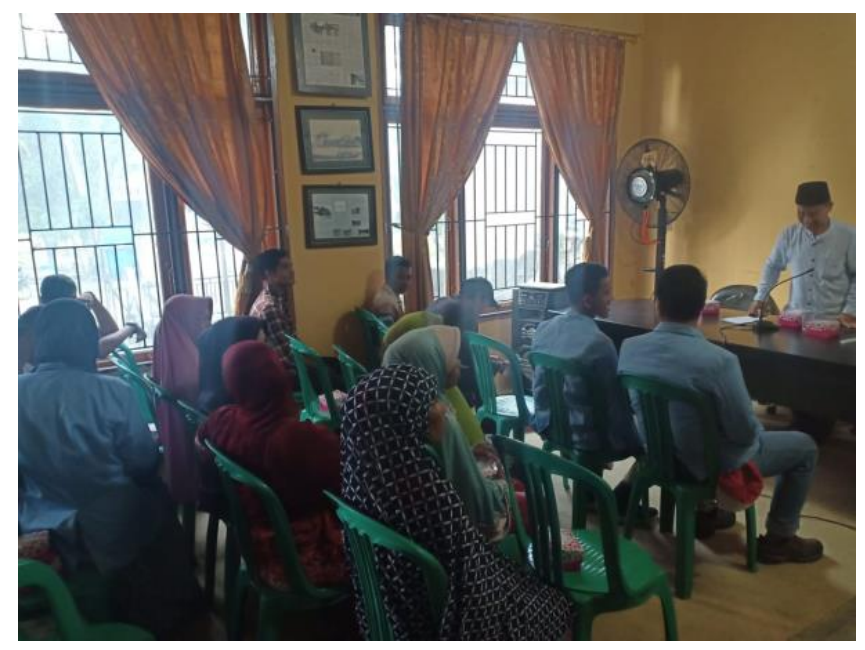

Gambar 4. Penyampaian Materi 


\section{Penyampaian Materi Penyuluhan Tentang Teknologi Pengoloahan air gambut}

Tahapan di ruang kelas/aula Desa Buluh Cina ini diawali dengan memberikan materi penyuluhan tentang pengolahan air gambut. Masyarakat dengan antusias memperhatikan materi penyuluhan yang disampaikan oleh Tim, serta prakteknya dibantu oleh mahasiswa Kukerta dalam kegiatan Kukerta terintegrasi seperti ditunjukkan pada Gambar 4.

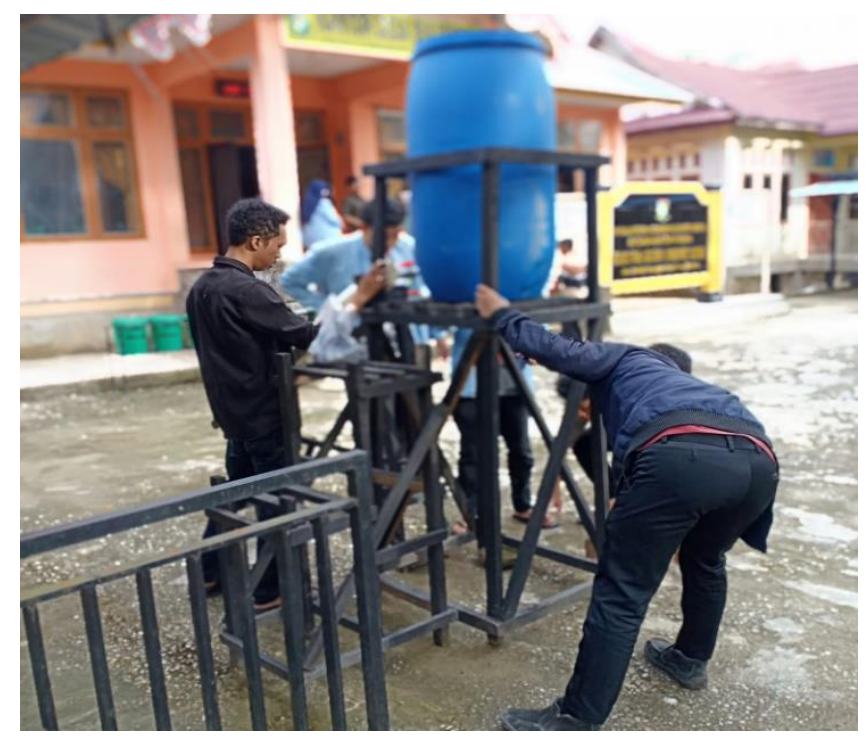

Gambar 5. Mahasiswa Sedang melakukan persiapan teknologi

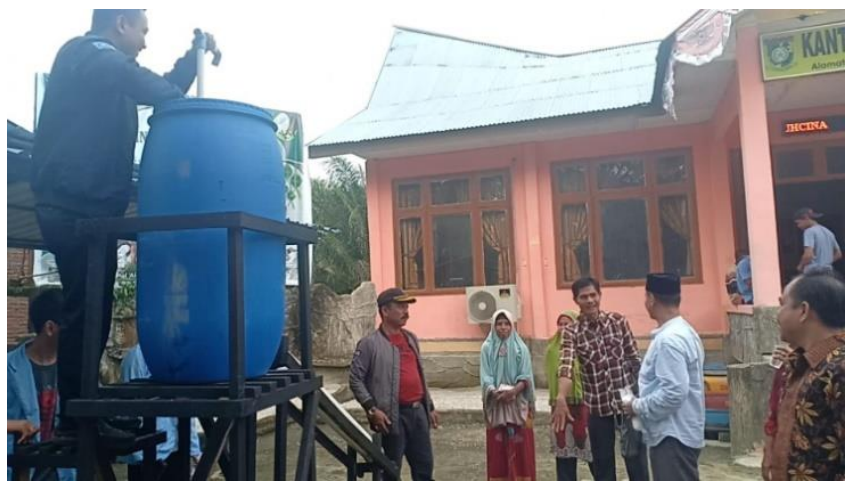

Gambar 6. Praktek Pengolahan air gambut menjadi air bersih

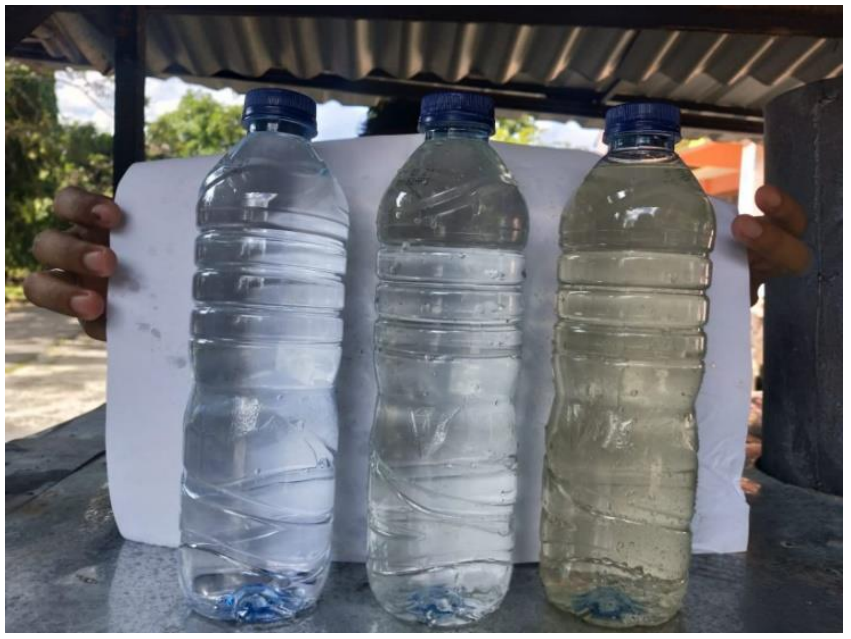

Gambar 7. Hasil pengolahan air gambut menjadi air bersih

Hasil teknologi kemudian dianalisis kadar kekeruhan dan warna air gambut. Nilai pH terendah sebelum filterisasi yaitu sebesar 5,93 dan $\mathrm{pH}$ tertinggi terdapat pada sebelum filterisasi yaitu 6,23. Artinya sebelum 
difilter air gambut bersifat asam lemah. Hasil sampel terendah setelah filterisasi dengan saringan pasir lambat yaitu sebesar 6,42 dan $\mathrm{pH}$ tertinggi setelah filterisasi sebesar 7,5 yang artinya air bersifat basa lemah. Batas $\mathrm{pH}$ air yang baik adalah 6,5 sampai dengan 8,5 sehingga penilitian ini membuktikan saringan pasir lambat dinilai cukup efektif untuk mengoptimalkan $\mathrm{pH}$ air. Total dissolved solid (TDS) merupakan salah satu parameter untuk menentukan suatu kualitas air, TDS menunjukkan jumlah padatan zat terlarut pada air.

\section{Evaluasi Kegiatan}

Hasil pengabdian tentang TDS air gambut diperoleh bahwa nilai TDS terendah sebelum filterisasi yaitu sebesar $46 \mathrm{mg} / \mathrm{L}$ dan TDS tertinggi terdapat pada sebelum filterisasi yaitu sebesar $49 \mathrm{mg} / \mathrm{L}$. Hasil sampel terendah setelah filterisasi dengan saringan pasir lambat yaitu $49 \mathrm{mg} / \mathrm{L}$ dan TDS tertinggi setelah filterisasi sebesar 83 . $\mathrm{Mg} / \mathrm{L}$.

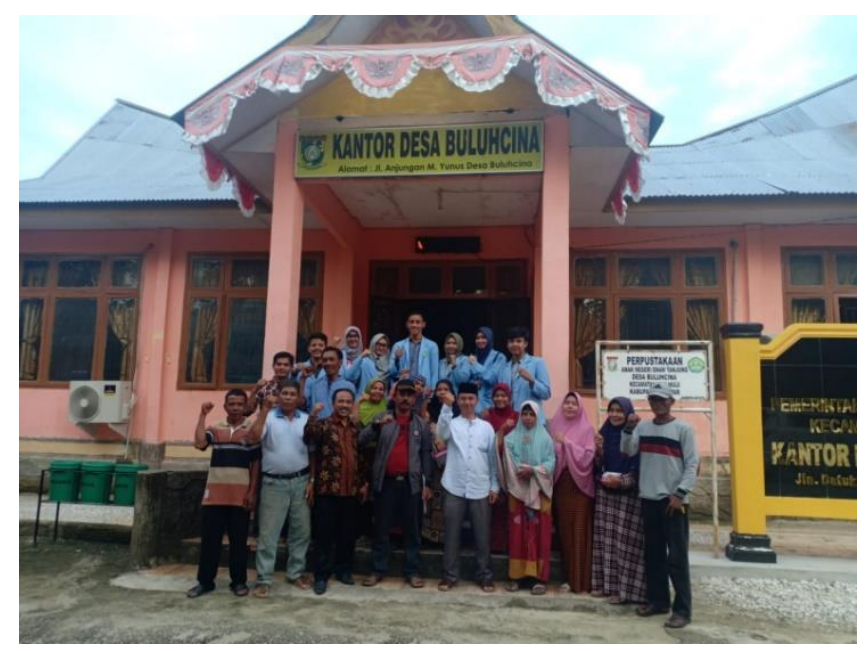

Gambar 8. Berfoto bersama selesai kegiatan

Seusai kegiatan pengabdian, maka semua peserta melakukan foto bersama (Gambar 8) yang terdiri dari Kepala Desa Buluh Cina, tokoh masyarakat, kelompok masyarakat, mahasiswa KUKERTA UNRI terintegrasi tahun 2019 dan dosen pembimbing (Dr. Juandi M. MSi).

\section{KESIMPULAN}

Berdasarkan hasil pelaksanaan pengabdian pada masyarakat yang telah dilakukan serta analisa, maka dapat diambil kesimpulan yaitu telah berhasil diterapkan teknologi pengolahan air gambut menjadi air bersih di Desa Buluh Cina Kecamatan Siak Hulu Kabupaten Kampar Provinsi Riau.

Perubahan yang terjadi dengan adanya pengabdian masyarakat ini adalah telah terjadi transfer teknologi pengolahan air gambut menjadi air bersih pada masyarakat di Desa Buluh Cina Kecamatan Siak Hulu, Kampar, selanjutnya masyarakat telah menyadari bahaya dari mengkonsumsi air gambut.

\section{UCAPAN TERIMA KASIH}

Ucapan terima kasih kepada LPPM Universitas Riau yang telah memberi bantuan dana, dan ucapan terimaksih kepada mahasiswa Kukerta yang telah membantu dalam praktek lapangan bersama masyarakat.

\section{DAFTAR PUSTAKA}

Effendi, H. 2003. Telaah Kualitas Air Bagi Pengelolaan Sumber Daya dan Lingkungan Perairan. Yogjakarta: Kanisius.

Sudadi, P. 2003. Penentuan Kualitas Air Tanah Melalui Analisis Unsur Kimia Terpilih. Bandung: Sub Direktorat Pendayagunaan Air Tanag DTLGP.

Sutrisno, C. 1987. Teknik Penyediaan Air Bersih. Jakarta: PT Bina Angkasa.

Taweel, E. G., and G. H. Ali. 2000. Evaluation of Roughing and Slow Sand Filters for Water Treatment. Water, Air, and Soil Pollution 120: 21-28 
Longsdon, G. S., R. Kohne, S. Abel, S. LaBonde. 2002. Slow Sand Filter for Small Water Treatment Systems. Journal of Environmental Engineering and Science 1(5): 339 - 348 